Review Article

\title{
Role of Cannabinoid Receptors in Psychological Disorder
}

Ambika Nand Jha $\mathbf{1}^{*}$ (0)
Dhaval M. Patel 2
1Department of Pharmacy Practice,
Indubhai Patel College of Pharmacy and
Research Center, Dharmaj, Gujarat,
India
2Department of Pharmacology, SAL
Institute of Pharmacy, Ahmedabad,
Gujarat, India
*email: nandjha99@gmail.com
Keywords:
Alzheimer
Anxiety
CB1 receptors
CB2 receptors
Endocannabinoid
Neurochemical

\begin{abstract}
Cannabinoid receptors, located throughout the body, are part of the endocannabinoid system. Cannabinoid CB1 and CB2 receptors are G protein-coupled receptors present from the early stages of gestation, which is involved in various physiological processes, including appetite, pain-sensation, mood, and memory. Due to the lipophilic nature of cannabinoids, it was initially thought that these compounds exert several biological effects by disrupting the cell membrane nonspecifically. Recent biochemical and behavioral findings have demonstrated that blockade of CB1 receptors engenders antidepressant-like neurochemical changes (increases in extracellular levels of monoamines in cortical but not subcortical brain regions) and behavioral effects consistent with antidepressant/antistress activity. We aim to define various roles of cannabinoid receptors in modulating signaling pathways and association with several pathophysiological conditions.
\end{abstract}

Received: July 29th, 2020

Accepted: September $24^{\text {th }}, 2020$

Published: November 30th, 2020

(C) 2020 Ambika Nand Jha, Dhaval M. Patel. Published by Institute for Research and Community Services Universitas Muhammadiyah Palangkaraya. This is an Open Access article under the CC-BY-SA License (http://creativecommons.org/licenses/by-sa/4.0/). DOI: https://doi.org/10.33084/bjop.v3i4.1569

\section{INTRODUCTION}

Psychological disorders are responsible for the largest proportion of the global burden of disease worldwide (Whiteford et al., 2015). It has been suggested that by 2030, depression will be the leading cause of disease burden globally (Lépine \& Briley, 2011). Uncontrolled excitotoxicity and neuroinflammation contribute to cell death and damage in neurological and neuropsychiatric diseases, including some that are related to stress exposure (neurodegenerative diseases, depression, posttraumatic stress disorder, and schizophrenia) (Tay et al., 2017).

Cannabis is touted to effectively attenuate a wide range of conditions, including asthma, inflammatory bowel disease, glaucoma, multiple sclerosis, menstrual cramps, AIDS, nausea, and cancer (Bruni et al., 2018). Delta-9tetrahydrocannabinol (THC) is the principal psychoactive constituent of cannabis, and most, if not all, of the effects associated with the use of cannabis, are caused by THC (Kimura et al., 2019). Beyond these effects on physical conditions, cannabis has been reported to improve neurocognitive and psychiatric conditions, such as Alzheimer's disease, anxiety disorders, and bipolar disorder (Abizaid et al., 2019; Sarris et al., 2020; Burggren et al.,2019). The endocannabinoid system (ECS) plays key modulatory roles during synaptic plasticity and homeostatic brain processes (Lu \& Mackie, 2016).

This review discusses some relationships between the cannabinoid (CB1 and CB2) receptors and their ligands with the nervous system in health and disease. We will introduce the two major receptors, focusing on the CB1 receptors due to their high expression levels in the CNS. Their endogenous ligands or endocannabinoids (ECB) and some synthetic mimetics that activate and modulate their signaling; the signaling pathways that connect this 
receptor to processes inside the cell; and the role of the $\mathrm{CB}$ system in the normally functioning CNS and its alteration or therapeutic modulation in a variety of disease states (Tanaka et al., 2020).

\section{OVERVIEW OF ENDOCANNABINOID SYSTEM}

Before discussing the ECS's functions, it is essential to understand its components. The ECS comprises cannabinoid receptors, endogenous ligands (binding molecules) for those receptors, and enzymes that synthesize and degrade the ligands (Stasiulewicz et al., 2020). Exogenous cannabinoids, such as tetrahydrocannabinol, produce their biological effects through their interactions with cannabinoid receptors. 2arachidonoyl glycerol (2-AG) and arachidonoyl ethanolamide (anandamide) are the best-studied endogenous cannabinoids (Lu \& Mackie, 2016).

The most well-known cannabinoid receptors are CB1 and CB2. Studies in the early 1990s provided initial evidence of the existence and purpose of CB1 and CB2 receptors. Both types of cannabinoid receptors are found throughout the entire body but are distributed differently (Zou \& Kumar, 2018). The CB1 receptors are concentrated primarily in the Central Nervous System, are most highly expressed by the axons and presynaptic terminal of neurons in the amygdala, hippocampus, cortex, basal ganglia outflow tracts, and cerebellum (Castillo et al., 2012). In contrast, CB2 receptors are mainly found in the immune system (Turcotte et al., 2016). However, CB1 receptors are also distributed in various peripheral areas like adipose (fat) tissue, and CB2 receptors are expressed to some degree in the brain (Howlett \& Abood, 2017).

$\mathrm{G}$ protein-coupled receptor (GPCR) domains comprise the extracellular $\mathrm{N}$ terminus, seven-transmembrane alpha-helices (TM), loops connecting the TMs, and an intracellular $\mathrm{C}$ terminus. Ligand binding generally occurs within a binding site gap formed by the TM bundle, directly to a pocket formed by the extracellular loops, or to a combination of extracellular loop and binding site gap residues (Wheatley et al., 2012). Binding induces a conformational change in the receptor, causing activation of a $G$ protein docked to the inner face, which initiates a specific cellular process (Black et al., 2016).

In general, an agonist-bound receptor activates an appropriate $G$ protein that promotes dissociation of GDP. The GPCR ligands fall into four categories depending on the nature of their interaction: agonists, antagonists, partial agonists, and inverse agonists (Weis \& Kobilka, 2018). Agonists bind to the receptor and elicit a cellular response by causing a conformational change. Antagonists bind, prevent agonists from binding, and do not elicit any response. A partial agonist is an intermediate class that, upon binding, does not invoke the complete agonist conformational change but still allows for partial activity. Simultaneously, they "block" the receptor from being available for full agonist binding. When both a full agonist and partial agonist are present, the partial agonist acts as a competitive antagonist, producing a net decrease in the receptor's activation. Inverse agonists bind to a receptor but induce a physiological response opposite to what would be expected from an agonist (Shahbazi et al., 2020; Berg \& Clarke, 2018). The affinity of a ligand for the receptor is independent of the role: weakly binding full agonists and strongly binding partial agonists are both known (Buchwald, 2019; Patel et al., 2019).

Agonists targeting CB2 receptors have been proposed to treat or manage a range of painful conditions, including acute pain, chronic inflammatory pain, and neuropathic pain (Dhopeshwarkar \& Mackie, 2014; Vučković et al., 2018; Donvito et al., 2018). The ECB system is primarily composed of two inhibitory GPCRs, CB1 and CB2, and 
two major endogenous ligands, Narachidonoylethanolamine (anandamide/AEA) and 2arachidonoylglycerol (2-AG). Besides, ECB signaling is highly regulated by metabolic enzymes, including fatty acid amide hydrolase (FAAH) and monoacylglyceride lipase (MAGL), hydrolyze AEA and 2-AG, respectively (Figure 1) (Meyer et al., 2018).

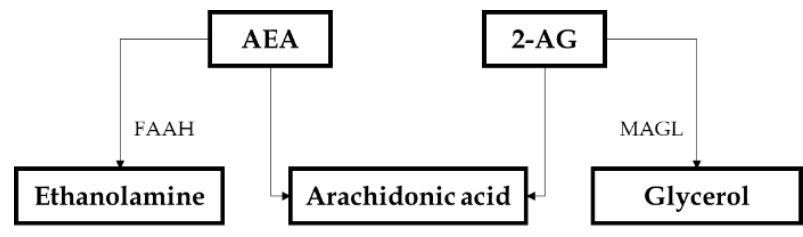

Figure 1. Major pathways of endocannabinoid degradation (Meyer et al., 2018)

\section{CANNABINOID RECEPTORS IN ANXIETY}

Anxiety disorders, the most prevalent of the psychiatric disorders, cause immeasurable suffering worldwide. Despite impressive advances in pharmacological therapies, improvements in efficacy and side-effect profiles are needed. Anxiety causes chemical changes in the limbic system, including the amygdala, hippocampus, and hypothalamus of the brain (Zou \& Kumar, 2018). The present literature review examines the role that the endocannabinoid system may play in these disorders and the potential value of targeting this system to search for novel and improved medications (Patel et al., 2017; Kayser et al., 2019).

The neural mechanisms by which endocannabinoid signaling affects anxiety are not well understood, yet several mechanisms at the systems, synaptic, and molecular level can be posed based on available data. The majority of available data indicate that ECS has anxiolytic properties in both conditioned and unconditioned anxiety models and that these effects are more active during states of stress or high arousal (Stasiulewicz et al., 2020; Patel \& Hillard, 2009). Endocannabinoid signaling's anxiolytic effects are mimicked by low doses of direct
CB1 receptor agonists (Hill et al., 2018). Thus, data exploiting this phenomenon can be used to increase our understanding of the neural mechanisms subserving the endocannabinoid signaling system's anxiolytic actions (Patel \& Hillard, 2009).

At the systems level, microinjections of low doses of the direct CB1 agonist THC into the prefrontal cortex (PFC) (Rubino et al., 2008), ventral hippocampus, and a dorsal periaqueductal gray area exert anxiolytic effects in the elevated plus-maze (Moreira et al., 2007). Stress relief and relaxation are frequently reported as drivers of cannabis use (Turna et al., 2017). These effects are blocked by the CB1 receptor antagonist AM251 (Boctor et al., 2007). Pharmacological inhibition of FAAH within the PFC produces CB1 receptor-dependent, anxiolytic effects, and over-expression of FAAH (which reduces local Narachidonoylethanolamine levels) causes the anxiogenic effect in the elevated plus-maze (Navarrete et al., 2020; Lutz et al., 2015).

In contrast to the PFC and hippocampus, very low THC doses produce only anxiogenic effects when administered into the basolateral amygdala (BLA); this was also dependent upon CB1 receptor activation. These data suggest that the PFC and hippocampus are likely anatomical sites of action that subserve ECS's anxiolytic effects. More specifically, the balance of ECS in favor of an increase in the PFC plus hippocampus and reduced signaling in the amygdala could be required for maximal anxiolytic effects (Patel \& Hillard, 2009). Endocannabinoid signaling differs from that of classical neurotransmitters. They are synthesized on demand in post-synaptic neurons in response to neuronal activation and act on their targets located presynaptically or in the post-synaptic neuron itself to mediate retrograde or nonretrograde signaling, respectively (Kano, 2014). Endocannabinoids act on presynaptic CB1 receptors during retrograde signaling to suppress in response to 
stimuli, which normally provoke anxiety. Both the anxiogenic and psychotropic effects of THC would appear to preclude its use for treating anxiety-related disorders, at least when administered on its own (Lee et al., 2017; Papagianni et al., 2019).

\section{NEURAL MECHANISMS OF ENDOCANNABINOID MODULATION IN DEPRESSION}

The neurobiology of depression is complex; however, a large body of evidence supports the hypothesis that dysregulation of the Hypothalamic-Pituitary-Adrenal axis (HPA axis) plays a critical role (Hasler, 2010). In particular, HPA axis hyperactivation and reduced feedback inhibition are seen in humans with depression and in animal models of depression. Anti-depressants' ability to suppress HPA axis hyperactivity is coupled with their clinical efficacy (Herman et al., 2016).

Recent studies strongly suggest that the ECS's primary role is to dampen HPA axis activation by stress and allow for appropriate stress recovery (Stephens \& Wand, 2012). These findings are consistent with the data obtained in rodents described above that ECS inhibition is generally pro-depressive. Simultaneously, its activation results in an anti-depressant phenotype and leads to the hypothesis that the HPA axis's dampening is the mechanism by which ECS interacts with depression. However, HPA axis inhibition does not entirely explain ECS's effects to alter coping behaviors in the forced swim assay (Barden, 2004). Poleszak et al. (2020) evaluated the potential interaction between the CB2 receptor ligands (i.e., JWH133 - CB2 receptor agonist and AM630 - CB2 receptor inverse agonist) and several common antidepressant drugs that influence the monoaminergic system (i.e., imipramine, escitalopram, reboxetine) (Ibarra-Lecue et al., 2018). Cannabis amotivational syndrome is based on apparent apathy and abolished the ability to concentrate and follow routine life observed in those who consume marijuana frequently (Volkow et al., 2016). There is both preclinical and clinical evidence supporting the view that cannabis use is associated with an amotivational state (Lawn et al., 2016). Considerable research has failed to identify a cannabis-specific motivational syndrome, and its existence remains controversial. A study by Lac and Luk (2018) sought to elucidate amotivational syndrome by examining connections between marijuana use and self-efficacy constructs of initiative, effort, and persistence. Results showed that marijuana intake was significantly longitudinally related to lower initiative and persistence in their college student sample. Due to this, higher dose THC should be avoided in people with major depressive disorder (MDD) or low mood. However, a crosssectional survey on patterns of use and perceived efficacy suggested that over 1429 participants identified as medical cannabis users, over 50\% reported using medicinal cannabis specifically for depression (Sarris et al., 2020). Various medicinal cannabis trials in mental disorders are listed in Table I, while various EC system changes in neurodegenerative disorders are listed in Table II.

Table I. Medicinal cannabis trials in mental disorders

\begin{tabular}{|c|c|c|c|}
\hline 宓克 & 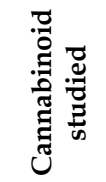 & 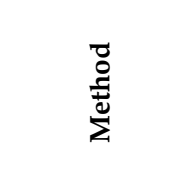 & 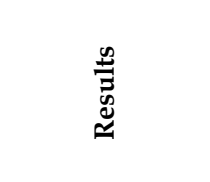 \\
\hline $\begin{array}{l}\text { Social anxiety } \\
\text { (Bergamaschi } \\
\text { et al., 2011) }\end{array}$ & $\begin{array}{l}\text { CBD } \\
(600 \mathrm{mg})\end{array}$ & $\begin{array}{l}24 \text { treatment- } \\
\text { naïve patients } \\
\text { with social } \\
\text { anxiety were } \\
\text { blindly } \\
\text { allocated to } \\
\text { receive CBD or } \\
\text { placebo } 1.5 \\
\text { hours before a } \\
\text { simulated } \\
\text { public speaking } \\
\text { test. } \\
\text { unmedicated } \\
\text { healthy controls } \\
\text { also completed } \\
\text { the test. Self- } \\
\text { reports on the } \\
\text { visual analogue } \\
\text { mood scale, } \\
\text { negative self- }\end{array}$ & $\begin{array}{l}\text { Pre-test CBD } \\
\text { administration in } \\
\text { social anxiety } \\
\text { patients versus } \\
\text { placebo, resulted } \\
\text { in significantly } \\
\text { reduced anxiety, } \\
\text { cognitive } \\
\text { impairment and } \\
\text { discomfort in } \\
\text { speech } \\
\text { performance, and } \\
\text { significantly } \\
\text { decreased } \\
\text { hyperalertness in } \\
\text { anticipatory } \\
\text { speech. CBD and } \\
\text { control groups } \\
\text { however did not } \\
\text { differ, reflecting }\end{array}$ \\
\hline
\end{tabular}




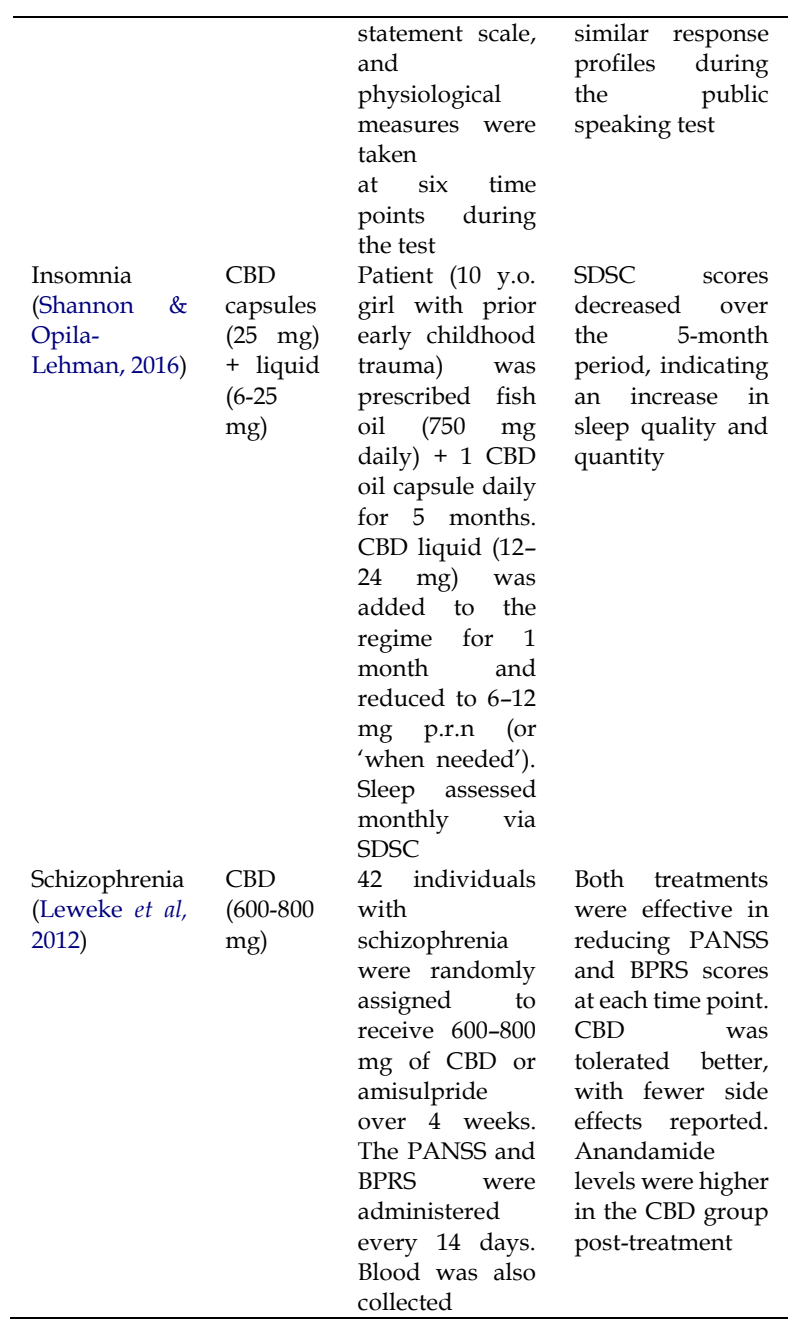

Table II. Changes in EC system in neurodegenerative disorders

\begin{tabular}{|c|c|}
\hline Study model & Changes in EC system \\
\hline $\begin{array}{l}\text { Changes in the EC system } \\
\text { components in Alzheimer } \\
\text { diseases, } \\
\text { studies, AbPPswe/PS1DE9 } \\
\text { model of AD (Maroof et al., } \\
\text { 2014) }\end{array}$ & $\begin{array}{l}<\text { Striatal AG level } \\
>\text { CBR/effector coupling }\end{array}$ \\
\hline $\begin{array}{l}\text { Changes in the EC system } \\
\text { components in Parkinson's } \\
\text { diseases, Pre-clinical } \\
\text { studies, Reserpine treated } \\
\text { rats (Di Marzo et al., 2000) }\end{array}$ & $\begin{array}{l}>2-A G \text { in globus pallidus } \\
\text { Impaired locomotion } \\
>\text { AEA in globus pallidus \& } \\
\text { substantia nigra }\end{array}$ \\
\hline $\begin{array}{l}\text { EC system targeted } \\
\text { pharmacological } \\
\text { compounds treating } \\
\text { Alzheimer diseases, Pre- } \\
\text { clinical studies, Ab injected } \\
\text { rats (Ramirez et al., 2005) }\end{array}$ & $\begin{array}{l}<\mathrm{Ab} \text { induced microglial } \\
\text { activation } \\
<\text { Cognitive impairment }\end{array}$ \\
\hline
\end{tabular}

\section{CANNABINOID RECEPTOR IN EPILEPSY}

Cannabidiol good affinity at the plausible concentration for 5-HT1A and 5-HT2A receptors, and 5-HT2A receptors act as a target for fenfluramine, a drug for which some evidence supports efficacy drug-resistant epilepsies such as Dravet syndrome (Ceulemans et al., 2012). A minimal number of studies have reported changes in 5-hydroxytryptamine (5-HT) receptor expression and function in people with epilepsy, although it remains unclear whether this is a consequence of the disease or a component of pathogenesis. Thus, while 5-HT involvement in pathogenesis remains uncertain, some 5-HT receptor subtypes may represent a valid therapeutic target in epilepsy through which CBD could be acting (Theodore et al., 2007; Theodore et al., 2012). Glycine receptor (GlyR) is predominantly expressed in the CNS, neuronal cells, brainstem, and spinal cord, and there is much less evidence of their role in disorders of the cerebrum, such as epilepsy. However, recent research in rodent species has shown significant, functional GlyR expression in cortex and hippocampus at least up to postnatal day 14, where they serve to modulate neuronal network function (Avila et al., 2013), and emerging evidence suggests a role in hyperexcitability disorders (Harvey et al., 2008). These findings suggest that investigation of GlyR function in healthy and epileptic, mature human cortex is warranted in order to lend further credence to GlyR-mediated antiepileptic effects of CBD.

\section{CANNABINOID RECEPTORS IN}

\section{ALZHEIMER'S DISEASE}

Alzheimer's disease (AD) is the most common neurodegenerative disease in Western Europe, and a significant public health problem as the number of cases increases with the aging of the population. It manifests with a progressive decline in memory and intellectual abilities, impoverishment of language, disorientation, and behavioral skills (Mayeux \& Stern, 2012). The AD is also characterized by enhanced beta-amyloid peptide $(\mathrm{A} \beta)$ deposition and glial activation in senile plaques, 
selective neuronal loss, and cognitive deficits (Licastro \& Chiappelli, 2003). The role of cannabinoid receptors in $\mathrm{AD}$ and their possible protective effects after $\mathrm{A} \beta$ treatment showed that senile plaques in $\mathrm{AD}$ patients express CB1 and CB2 cannabinoid receptors and markers of microglial activation (Pizza et al., 2011). Furthermore, while high levels of CB1-positive neurons are present in control cases, they are significantly reduced in microglial activation areas. Also, G-protein coupling and CB1 receptor protein expression are markedly decreased in $\mathrm{AD}$ brains where protein nitration is increased (Ramirez et al., 2005). Cannabinoids prevent both $A \beta$-induced microglial activation, cognitive impairment, and loss of neuronal markers and abrogate microglia-mediated neurotoxicity after $\mathrm{A} \beta$ addition to rat cortical cocultures. These results indicate that cannabinoid receptors are involved in the pathology of $\mathrm{AD}$ and that they may control the neurodegenerative process occurring in the disease (Cassano et al., 2017).

\section{CONCLUSION}

Stress-related mood and anxiety disorders affect millions of people in the United States. Endocannabinoids are lipids that act as a kind of a neurotransmitter. Mainly, they activate the $\mathrm{CB} 1$ and $\mathrm{CB} 2$ brain receptors. $\mathrm{CB} 1$ can be found in several brain areas, including the neocortex, the hippocampus, the amygdala, the cerebellum, and the hypothalamus. These brain areas are involved in emotional and behavioral reactions, homeostasis, learning, memory, and decision-making. The effects on emotion mediated by cannabinoid compounds are believed to be due to regulating activity at the cannabinoid CB1 receptors. However, some limited evidence implicates the cannabinoid CB2 and a putative novel cannabinoid receptor (GPR55) in some observed emotional responses. Effects on emotion are likely the result of a net effect of the summated neurochemical responses. Compounds that indirectly regulate activity at the cannabinoid receptors more consistently reduce anxiety both in preclinical and clinical models.

\section{ACKNOWLEDGMENT}

We want to express our sincere gratitude to Dr. Dhaval M. Patel, Professor Department of Pharmacology, SAL Institute of Pharmacy, Ahmedabad. This review did not receive any specific grant from funding agencies in the public, commercial, or not-for-profit sectors. The author has no conflicts of interest to declare.

\section{REFERENCES}

Abizaid, A., Merali, Z., \& Anisman, H. (2019). Cannabis: A potential efficacious intervention for PTSD or simply snake oil? Journal of Psychiatry and Neuroscience, 44(2), 75-78. doi:10.1503/jpn.190021

Avila, A., Nguyen, L., \& Rigo, J.M. (2013). Glycine receptors and brain development. Frontiers in Cellular Neuroscience, 7, 184. doi:10.3389/fncel.2013.00184

Barden, N. (2004). Implication of the hypothalamicpituitary-adrenal axis in the physiopathology of depression. Journal of Psychiatry and Neuroscience, 29(3), 185-193.

Berg, K.A. \& Clarke, W.P. (2018). Making Sense of Pharmacology: Inverse Agonism and Functional Selectivity. International Journal of Neuropsychopharmacology, 21(10), 962-977. doi:10.1093/ijnp/pyy071

Bergamaschi, M.M., Queiroz, R.H.C., Chagas, M.H.N., de Oliveira, D.C.G., De Martinis, B.S., Kapczinski, F., Quevedo, J., Roesler, R., Schröder, N., Nardi, A.E., Martín-Santos, R., Hallak, J.E.C., Zuardi, A.W., \& Crippa, J.A.S. (2011). Cannabidiol reduces the anxiety induced by simulated public speaking in treatment-naïve social phobia patients. Neuropsychopharmacology, 36(6), 1219-1226. doi:10.1038/npp.2011.6

Black, J.B., Premont, R.T., \& Daaka, Y. (2016). Feedback Regulation of G Protein-Coupled Receptor 
Signaling by GRKs and Arrestins. Seminars in Cell and Developmental Biology, 50, 95-104. doi:10.1016/j.semcdb.2015.12.015

Boctor, S.Y., Martinez, J.L., Koek, W., \& France, C.P. (2007). The cannabinoid CB1 receptor antagonist AM251 does not modify methamphetamine reinstatement of responding. European Journal of Pharmacology, 571(1),39-43. doi:10.1016/j.ejphar.2007.06.004

Bruni, N., Pepa, C.D., Oliaro-Bosso, S., Pessione, E., Gastaldi, D., \& Dosio, F. (2018). Cannabinoid Delivery Systems for Pain and Inflammation Treatment. Molecules, 23(10), 2478. doi:10.3390/molecules23102478

Buchwald, P. (2019). A Receptor Model with Binding Affinity, Activation Efficacy, and Signal Amplification Parameters for Complex Fractional Response Versus Occupancy Data. Frontiers in Pharmacology, 10, 605. doi:10.3389/fphar.2019.00605

Burggren, A.C., Shirazi, A., Ginder, N., \& London, E.D. (2019). Cannabis effects on brain structure, function, and cognition: considerations for medical uses of cannabis and its derivatives. American Journal of Drug and Alcohol Abuse, 45(6),

563-579. doi:10.1080/00952990.2019.1634086

Cassano, T., Calcagnini, S., Pace L., De Marco, F., Romano, A., \& Gaetani, S. (2017). Cannabinoid Receptor 2 Signaling in Neurodegenerative Disorders: From Pathogenesis to a Promising Therapeutic Target. Frontiers in Neuroscience, 11,30. doi:10.3389/fnins.2017.00030

Castillo, P.E., Younts, T.J., Chávez, A.E., \& Hashimotodani, Y. (2012). Endocannabinoid signaling and synaptic function. Neuron, 76(1), 70-81. doi:10.1016/j.neuron.2012.09.020

Ceulemans, B., Boel, M., Leyssens, K., Van Rossem, C., Neels, P., Jorens, P.G., \& Lagae, L. (2012). Successful use of fenfluramine as an add-on treatment for Dravet syndrome. Epilepsia, 53(7), 1131-1139. doi:10.1111/j.15281167.2012.03495.x

Di Marzo, V., Hill, M.P., Bisogno, T., Crossman, A.R., \& Brotchie, J.M. (2000). Enhanced levels of endogenous cannabinoids in the globus pallidus are associated with a reduction in movement in an animal model of Parkinson's disease. The FASEB Journal, 14(10), 1432-1438. doi:10.1096/fj.14.10.1432

Donvito, G., Nass, S.R., Wilkerson, J.L., Curry, Z.A., Schurman, L.D., Kinsey, S.G., \& Lichtman, A.H. (2018). The Endogenous Cannabinoid System: A Budding Source of Targets for Treating Inflammatory and Neuropathic Pain. Neuropsychopharmacology, $\quad 43, \quad 52-79$. doi:10.1038/npp.2017.204

Dhopeshwarkar, A. \& Mackie, K. (2014). CB2 Cannabinoid Receptors as a Therapeutic Target-What Does the Future Hold? Molecular Pharmacology, 86(4), 430-437. doi:10.1124/mol.114.094649

Harvey, R.J., Carta, E., Pearce, B.R., Chung, S.K., Supplisson, S., Rees, M.I., \& Harvey, K. (2008). A Critical Role for Glycine Transporters in Hyperexcitability Disorders. Frontiers in Molecular Neuroscience, 1, 1. doi:10.3389/neuro.02.001.2008

Hasler, G. (2010). Pathophysiology of Depression: Do We Have Any Solid Evidence of Interest to Clinicians? World Psychiatry, 9(3), 155-161. doi:10.1002/j.2051-5545.2010.tb00298.x

Herman, J.P., McKlveen, J.M., Ghosal, S., Kopp, B., Wulsin, A., Makinson, R., Scheimann, J., \& Myers, B. (2016). Regulation of the hypothalamic-pituitary-adrenocortical stress response. Comprehensive Physiology, 6(2), 603621. doi:10.1002/cphy.c150015

Hill, M.N., Campolongo, P., Yehuda, R., \& Patel, S. (2018). Integrating Endocannabinoid Signaling and Cannabinoids into the Biology and Treatment of Posttraumatic Stress Disorder. Neuropsychopharmacology, 43(1), 80-102. doi:10.1038/npp.2017.162

Howlett, A.C. \& Abood, M.E. (2017). CB1 \& CB2 Receptor Pharmacology. Advances in Pharmacology, 80, 169-206. doi:10.1016/bs.apha.2017.03.007

Ibarra-Lecue, I., Pilar-Cuéllar, F., Muguruza, C., FlorensaZanuy, E., Díaz, Á., Urigüen, L., Castro, E., Pazos, A., \& Callado, L.F. (2018). The endocannabinoid system in mental disorders: Evidence from human brain studies. Biochemical Pharmacology, 157, 97-107. doi:10.1016/j.bcp.2018.07.009 
Kano, M. (2014). Control of synaptic function by endocannabinoid-mediated retrograde signaling. Proceedings of the Japan Academy Series B: Physical and Biological Sciences, 90(7), 235-250. doi:10.2183/pjab.90.235

Kayser, R.R., Snorrason, I., Haney, M., Lee, F.S., \& Simpson, H.B. (2019). The Endocannabinoid System: A New Treatment Target for Obsessive Compulsive Disorder? Cannabis and Cannabinoid Research, 4(2), 77-87. doi:10.1089/can.2018.0049

Kimura, T., Takaya, M., Usami, N., Watanabe, K., \& Yamamoto, I. (2019). $\quad \Delta 9$ Tetrahydrocannabinol, a major marijuana component, enhances the anesthetic effect of pentobarbital through the CB1 receptor. Forensic Toxicology, 37(1), 207-214. doi:10.1007/s11419-018-0457-2

Lac, A. \& Luk, J.W. (2018). Testing the Amotivational Syndrome: Marijuana Use Longitudinally Predicts Lower Self-Efficacy Even After Controlling for Demographics, Personality, and Alcohol and Cigarette Use. Prevention Science, 19(2), 117-126. doi:10.1007/s11121-0170811-3

Lawn, W., Freeman, T.P., Pope, R.A., Joye, A., Harvey, L., Hindocha, C., Mokrysz, C., Moss, A., Wall, M.B., Bloomfield, M.A., Das, R.K., Morgan, C.J., Nutt, D.J., \& Curran, V. (2016). Acute and chronic effects of cannabinoids on effortrelated decision-making and reward learning: an evaluation of the cannabis 'amotivational' hypotheses. Psychopharmacology, 233(19-20), 3537-3552. doi:10.1007/s00213-016-4383-x

Lee, J.L.C., Bertoglio, L.J., Guimarães, F.S., \& Stevenson, C.W. (2017). Cannabidiol regulation of emotion and emotional memory processing: relevance for treating anxiety-related and substance abuse disorders. British Journal of Pharmacology, 174(19), 3242-3256. doi:10.1111/bph.13724

Lépine, J.P. \& Briley, M. (2011). The increasing burden of depression. Neuropsychiatric Disease and Treatment, 7(Suppl 1), 3-7. doi:10.2147/NDT.S19617

Leweke, F.M., Piomelli, D., Pahlisch, F., Muhl, D., Gerth, C.W., Hoyer, C., Klosterkötter,J., Hellmich, M., \& Koethe, D. (2012). Cannabidiol enhances anandamide signaling and alleviates psychotic symptoms of schizophrenia. Translational Psychiatry, 2(3), e94. doi:10.1038/tp.2012.15

Licastro, F. \& Chiappelli, M. (2003). Brain immune responses cognitive decline and dementia: relationship with phenotype expression and genetic background. Mechanisms of Ageing and Development, 124(4), 539-548. doi:10.1016/S0047-6374(03)00034-4

Lu, H.C. \& Mackie, K. (2016). An introduction to the endogenous cannabinoid system. Biological Psychiatry, 79(7), 516-525. doi:10.1016/j.biopsych.2015.07.028

Lutz, B., Marsicano, G., Maldonado, R., \& Hillard, C.J. (2015). The endocannabinoid system in guarding against fear, anxiety and stress. Nature Reviews Neuroscience, 16(12), 705-718. doi:10.1038/nrn4036

Maroof, N., Ravipati, S., Pardon, M.C., Barrett, D.A., \& Kendall, D.A. (2014). Reductions in endocannabinoid levels and enhanced coupling of cannabinoid receptors in the striatum are accompanied by cognitive impairments in the A $\beta$ PPswe/PS1 $\triangle$ E9 mouse model of Alzheimer's disease. Journal of Alzheimer's Disease, 42(1), 227-245. doi:10.3233/jad-131961

Mayeux, R. \& Stern, Y. (2012). Epidemiology of Alzheimer Disease. Cold Spring Harbor Perspectives in Medicine, 2(8), a006239. doi:10.1101/cshperspect.a006239

Meyer, H.C., Lee, F.S., \& Gee, D.G. (2018). The Role of the Endocannabinoid System and Genetic Variation in Adolescent Brain Development. Neuropsychopharmacology, 43, 21-33. doi:10.1038/npp.2017.143

Moreira, F.A., Aguiar, D.C., \& Guimarães, F.S. (2007). Anxiolytic-like effect of cannabinoids injected into the rat dorsolateral periaqueductal gray. Neuropharmacology, 52(3), 958-965. doi:10.1016/j.neuropharm.2006.10.013

Navarrete, F., García-Gutiérrez, M.S., Jurado-Barba, R., Rubio, G., Gasparyan, A., Austrich-Olivares, A., \& Manzanares, J. (2020). Endocannabinoid System Components as Potential Biomarkers in Psychiatry. Frontiers in Psychiatry, 11, 315. doi:10.3389/fpsyt.2020.00315 
Papagianni, E.P. \& Stevenson, C.W. (2019). Cannabinoid Regulation of Fear and Anxiety: An Update. Current Psychiatry Reports, 21(6), 38. doi:10.1007/s11920-019-1026-z

Patel, D.M., Patel, A.B., Trivedi, R.D., Parmar, V.J., \& Bangoriya, U.V.(2019). Evaluation of the Effect of Hydroalcoholic Extracts of Cassia Occidentalis Leaves in Neutrophil Adhesion Test in Rats. Journal of Drug Delivery and Therapeutics, $\quad 9(4-S), \quad$ 1218-1221. doi:10.22270/jddt.v9i4-s.3940

Patel, S., Hill, M.N., Cheer, J.F., Wotjak, C.T., \& Holmes, A. (2017). The endocannabinoid system as a target for novel anxiolytic drugs. Neuroscience and Biobehavioral Reviews, 76(Pt A), 56-66. doi:10.1016/j.neubiorev.2016.12.033

Patel, S. \& Hillard, C.J. (2009). Role of Endocannabinoid Signaling in Anxiety and Depression. Current Topics in Behavioral Neurosciences, 1, 1-21. doi:10.1007/978-3-540-88955-7_14

Pizza, V., Agresta, A., D’Acunto, C.W., Festa, M., \& Capasso, A. (2011). Neuroinflamm-aging and neurodegenerative diseases: an overview. CNS and Neurological Disorders - Drug Targets, 10(5), 621-634. doi:10.2174/187152711796235014

Poleszak, E., Wośko, S., Sławińska, K., Wyska, E., Szopa, A., Sobczyński, J., Wróbel, A., Doboszewska, U., Wlaź, P., Wlaź, A., Szponar, J., Skałecki, P., \& Serefko, A. (2020). Ligands of the CB2 cannabinoid receptors augment activity of the conventional antidepressant drugs in the behavioural tests in mice. Behavioural Brain Research, 378, 112297. doi:10.1016/j.bbr.2019.112297

Ramírez, B.G., Blázquez, C., del Pulgar, T.G., Guzmán, M., \& de Ceballos, M.L. (2005). Prevention of Alzheimer's disease pathology by cannabinoids: neuroprotection mediated by blockade of microglial activation. Journal of Neuroscience, 25(8), 1904-1913. doi:10.1523/jneurosci.4540-04.2005

Rubino, T., Guidali, C., Vigano, D., Realini, N., Valenti, M., Massi, P., \& Parolaro, D. (2008). CB1 receptor stimulation in specific brain areas differently modulate anxiety-related behaviour. Neuropharmacology, 54(1), 151-160. doi:10.1016/j.neuropharm.2007.06.024
Sarris, J., Sinclair, J., Karamacoska, D., Davidson, M., \& Firth, J. (2020). Medicinal cannabis for psychiatric disorders: a clinically-focused systematic review. BMC Psychiatry, 20, 24. doi:10.1186/s12888-019-2409-8

Shahbazi, F., Grandi, V., Banerjee, A., \& Trant, J.F. (2020). Cannabinoids and Cannabinoid Receptors: The Story so Far. iScience, 23(7), 101301. doi:10.1016/j.isci.2020.101301

Shannon, S. \& Opila-Lehman, J. (2016). Effectiveness of Cannabidiol Oil for Pediatric Anxiety and Insomnia as Part of Posttraumatic Stress Disorder: A Case Report. The Permanente Journal, 20(4), 108-111. doi:10.7812/tpp/16-005

Stasiulewicz, A., Znajdek, K., Grudzień, M., Pawiński, T., \& Sulkowska, J.I. (2020). A Guide to Targeting the Endocannabinoid System in Drug Design. International Journal of Molecular Sciences, 21(8), 2778. doi:10.3390/ijms21082778

Stephens, M.A.C. \& Wand, G. (2012). Stress and the HPA Axis: Role of Glucocorticoids in Alcohol Dependence. Alcohol Research, 34(4), 468-483.

Tanaka, M., Sackett, S., \& Zhang, Y. (2020). Endocannabinoid Modulation of Microglial Phenotypes in Neuropathology. Frontiers in Neurology, 11,87. doi:10.3389/fneur.2020.00087

Tay, T.L., Béchade, C., D'Andrea, I., St-Pierre, M.K., Henry, M.S., Roumier, A., \& Tremblay, M.E. (2017). Microglia Gone Rogue: Impacts on Psychiatric Disorders across the Lifespan. Frontiers in Molecular Neuroscience, 10, 421. doi:10.3389/fnmol.2017.00421

Theodore, W.H., Wiggs, E.A., Martinez, A.R., Dustin, I.H., Khan, O.I., Appel, S., Reeves-Tyer, P., \& Sato, S. (2012). Serotonin 1A receptors, depression, and memory in temporal lobe epilepsy. Epilepsia, 53(1), 129-133. doi:10.1111/j.1528-1167.2011.03309.x

Theodore, W.H., Hasler, G., Giovacchini, G., Kelley, K., Reeves-Tyer, P., Herscovitch, P., \& Drevets, W. (2007). Reduced hippocampal 5HT1A PET receptor binding and depression in temporal lobe epilepsy. Epilepsia, 48(8), 1526-1530. doi:10.1111/j.1528-1167.2007.01089.x

Turcotte, C., Blanchet, M.R., Laviolette, M., \& Flamand, N. (2016). The CB2 receptor and its role as a regulator of inflammation. Cellular and 
Molecular Life Sciences, 73(23), 4449-4470. doi:10.1007/s00018-016-2300-4

Turna, J., Patterson, B., \& Van Ameringen, M. (2017). Is cannabis treatment for anxiety, mood, and related disorders ready for prime time? Depression and Anxiety, 34(11), 1006-1017. doi:10.1002/da.22664

Volkow, N.D., Swanson, J.M., Evins, L.E., DeLisi, L.E., Meier, M.H., Gonzalez, R., Bloomfield, M.A.P., Curran, H.V., \& Baller, R. (2016). Effects of Cannabis Use on Human Behavior, Including Cognition, Motivation, and Psychosis: A Review. JAMA Psychiatry, 73(3), 292-297. doi:10.1001/jamapsychiatry.2015.3278

Vučković, S., Srebro, D., Vujović, K.S., Vučetić, Č., \& Prostran, M. (2018). Cannabinoids and Pain: New Insights from Old Molecules. Frontiers in $\begin{array}{lll}\text { Pharmacology, } & 9, & \end{array}$ doi:10.3389/fphar.2018.01259

Weis, W.I. \& Kobilka, B.K. (2018). The Molecular Basis of G Protein-Coupled Receptor Activation. Annual Review of Biochemistry, 87, 897-919. doi:10.1146/annurev-biochem-060614-033910

Wheatley, M., Wooten, D., Conner, M.T., Simms, J., Kendrick, R., Logan, R.T., Poyner, D.R., \& Barwell, J. (2012). Lifting the lid on GPCRs: the role of extracellular loops. British Journal of Pharmacology, 165(6), 1688-1703. doi:10.1111/j.1476-5381.2011.01629.x

Whiteford, H.A., Ferrari, A.J., Degenhardt, L., Feigin, V., \& Vos, T. (2015). The Global Burden of Mental, Neurological and Substance Use Disorders: An Analysis from the Global Burden of Disease Study 2010. PLoS One, 10(2), e0116820. doi:10.1371/journal.pone.0116820

Zou, S. \& Kumar, U. (2018). Cannabinoid Receptors and the Endocannabinoid System: Signaling and Function in the Central Nervous System. International Journal of Molecular Sciences, 19(3), 833. doi:10.3390/ijms19030833 